\title{
Migration and fuel use in rural Zambia
}

\author{
Yu Wu ${ }^{1}$ D Barbara Entwisle $e^{1,2} \cdot$ Cyrus Sinai $^{1,3} \cdot$ Sudhanshu Handa ${ }^{1,4}$
}

Accepted: 27 April 2021/ Published online: 17 June 2021

(c) The Author(s) 2021

\begin{abstract}
What is the effect of migration on fuel use in rural Zambia? Opportunities to increase income can be scarce in this setting; in response, households may pursue a migration strategy to increase resources as well as to mitigate risk. Migrant remittances may make it possible for households to shift from primary reliance on firewood to charcoal, and the loss of productive labor through migration may reinforce this shift. This paper uses four waves of panel data collected as part of the Child Grant Programme in rural Zambia to examine the connection between migration and the choice of firewood or charcoal as cooking fuel and finds evidence for both mechanisms. Importantly, this paper considers migration as a process, including out as well as return migration, embedding it in the context of household dynamics generally. Empirical results suggest that while out-migration helps move households away from firewood as a fuel source, return migration moves them back, but because the former is more common, the overall effect of migration is to shift households away from primary reliance on firewood.
\end{abstract}

Keywords Energy poverty $\cdot$ Fuel use $\cdot$ Migration $\cdot$ Household dynamics $\cdot$ Zambia

\section{Introduction}

Migration is an important livelihood strategy in low-and-middle-income countries (LMICs), especially in rural areas where agriculture represents the dominant economic activity (De Haas, 2010; Qin, 2010). In places where capital, insurance, and credit markets are underdeveloped, rural households may diversify against the risks of weather, low crop yields, and price fluctuations inherent in agricultural production

Yu Wu

yuwu5@unc.edu

1 Carolina Population Center, University of North Carolina, Chapel Hill, NC 27516, USA

2 Department of Sociology, University of North Carolina, Chapel Hill, NC 27516, USA

3 Department of Geography, University of North Carolina, Chapel Hill, NC 27516, USA

4 Department of Public Policy, University of North Carolina, Chapel Hill, NC 27516, USA 
by sending one or more household members to another area subject to a different set of risks (Massey et al., 1993; Stark \& Bloom, 1985; Taylor, 1999). Destinations are sometimes international, sometimes not. Remittances from international migrants to LMICs have exceeded $\$ 500$ million in recent years, three times the amount of overseas development aid and foreign direct investment combined (United Nations, 2019). Although national accounts do not track remittances from internal migrants, these flows are undoubtedly significant as well, given that the number of internal migrants is estimated to be four times the number of international migrants (Ratha, 2013). However, migration does not always result in a benefit to the sending household. Not all migrants remit, and even those who do may not remit much, as this depends on their ability to find a job and how well it pays. Whether migrants remit also depends on the strength of their connection to the sending household, which may weaken with time and with the accumulation of obligations to new families. Even if migrants remit, their departure results in a loss of productive labor from the sending household (Manning \& Taylor, 2014; Rozzelle et al., 1999). Whether migration is a net benefit ultimately depends on the balance of remittances against the value of the labor lost. As a household strategy, migration is not without risk.

Of interest in this paper is whether migration as a livelihood strategy encourages a transition away from biomass fuel (such as wood, charcoal, animal dung, agricultural residues) as a household energy source. Nearly half of the world's population today relies on biomass fuel as their primary source of household energy for cooking and heating (IEA, 2017). Biomass fuel use varies significantly by region across the world, accounting for more than half of domestic energy sources in developing countries and up to $95 \%$ in some of the world's lowest income countries (Ezzati \& Kammen, 2002). Within these countries, there are often stark urban-rural divides in household energy sources, with rural households disproportionately relying on biomass fuels compared to urban households.

A reduction in the use of biomass fuel could have important health benefits. Exposure to indoor air pollution from the combustion of biomass fuels is a leading cause of mortality in developing countries (Ezzati \& Kammen, 2002). These pollutants are associated with respiratory infections such as pneumonia, tuberculosis, chronic obstructive pulmonary disease (COPD), lung cancer, and asthma, as well as other health problems such as low birth weight, cataracts, and stroke (Kim et al., 2011). Women and children disproportionately bear the health burdens caused by exposure to biomass smoke, as in most LMICs, women are primarily responsible for cooking for the family (WHO, 2018). Further, a reduction in the use of biomass fuels could have environmental benefits. Although evidence suggests that deforestation in rural areas is more likely driven by agricultural growth, residential development, and climate change (Jagger \& Kittner, 2017; Ribot, 1999), firewood collection and the production of charcoal in more densely populated areas can affect forest environments, especially those proximate to urban areas (Megevand et al., 2013; Zulu \& Richardson, 2013).

This paper investigates migration and household fuel choice, or fuel use, in subSaharan Africa, where biomass fuel is used more than any other region in the world (Jagger \& Shively, 2014), and where the majority of rural and poor urban households depend on biomass fuels for their cooking needs (Makonese et al., 2018). Of 


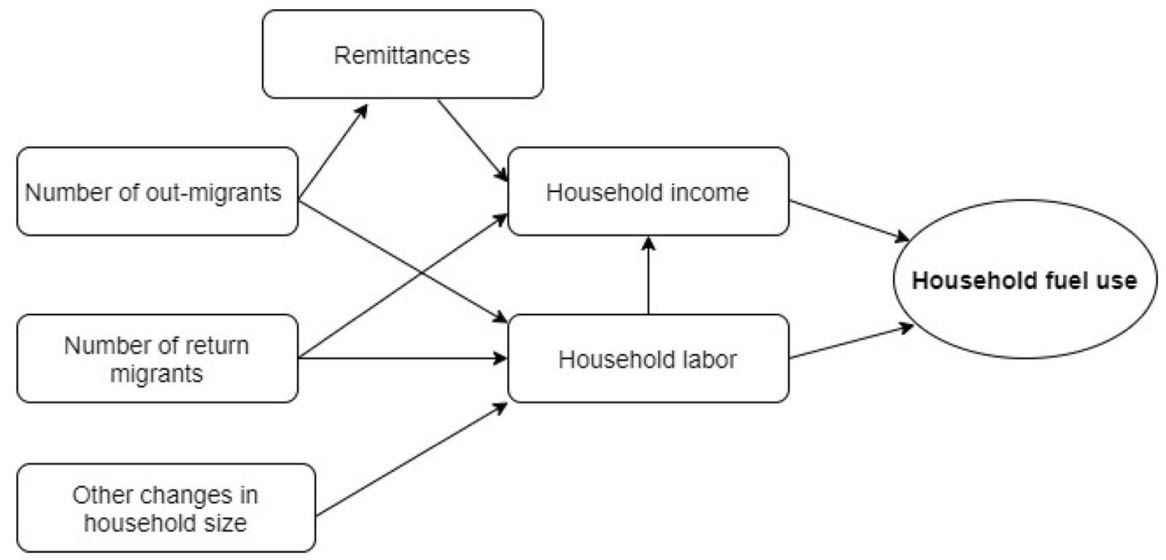

Fig. 1 A conceptual model of the effects of migration and remittances on household fuel choice

particular interest is the shift from firewood to charcoal, often called a "transition fuel," as it can signal the beginning of a larger shift away from biomass fuel, especially as charcoal is often a purchased fuel. Our study uses four waves of panel data collected between 2010 and 2017 as part of the impact evaluation of the Child Grant Programme (CGP) in rural Zambia. We use these data to explore the consequences of migration and other changes in household membership for household fuel use. Households are dynamic, changing in a myriad of ways potentially relevant to labor allocation decisions and choices about fuel use. This paper is the first study on household fuel use to compare migration to other changes in household membership and as a related point, the first to consider return migration as well as out-migration. The next section justifies these claims through a discussion of the existing literature on migration and fuel use. We then describe the setting for our study, the data, the measurement of key variables, and the specification and estimation of our fixedeffects models. This is followed by a presentation of our results. To preview, our results point to the importance of both out- and return migration for influencing fuel use in rural Zambia and to both labor availability and remittances as mechanisms explaining these effects.

\section{Background}

As a household livelihood strategy, migration can affect choice of fuel in two different ways $^{1}$ (see Fig. 1). First, remittances sent back by migrating household members can provide the liquidity that households need to purchase fuels and

\footnotetext{
1 By changing household size, migration might also influence the amount of fuel used through effects on demand (Chen et al., 2006; Wang et al., 2012; Gong, 2011; Qin, 2010). However, our interest is in the choice of fuel, not the amount used.
} 
enable them to consume more expensive, modern energy sources by increasing their income (Manning \& Taylor, 2014; Qin, 2010; Song et al., 2018; Taylor et al., 2011). Remittances are not always sent but may be brought back by returning migrants when they reach their income targets (e.g., Piotrowski \& Tong, 2010). Under this mechanism, both out-migration and return-migration could decrease the use of inferior fuels such as firewood. Second, migration can affect the availability of household labor for agricultural production and firewood collection. Households with out-migrants may become more labor-constrained, increasing the opportunity costs of time-consuming firewood collection, and thereby pushing the household to adopt alternative fuels (Gong, 2011; Hou et al., 2017; Manning \& Taylor, 2014; Wang et al., 2012). Of course, labor lost to migration is potentially restored with the migrants' return. Therefore, under the labor allocation mechanism, out-migration will decrease the use of firewood, but return-migration will have the reverse effect. We view migration as a process, embedded in a larger system of interconnections between places of origin and places of destination (Entwisle et al., 2020), and involving movement in both directions, out and return.

The empirical literature addressing migration and household fuel use is relatively sparse. Research on the consequences of migration typically focuses on income and poverty (Christiaensen et al., 2019; Gupta et al., 2009; Lokshin et al., 2010; Rozelle et al., 1999), rarely considering fuel use as a possible outcome. Likewise, research on the determinants of fuel use rarely considers migration (Muller \& Yan, 2018). Many of the studies of household fuel use that do actually mention migration deal with the topic indirectly, such as estimating changes in population exposure to household air pollution due to large-scale rural-to-urban migration and associated changes in cooking practices (Aunan \& Wang, 2014; Komatsu et al., 2013; Ru et al., 2015; Shen et al., 2017), or studying household fuel use in an area where migration is highly prevalent but is discussed as context in the study setting rather than examined explicitly as a potential determinant (Adelekan \& Jerome, 2006; Hughes-Cromwick, 1985; Jagger \& Shively, 2014; Wang et al., 2012). To date, there have been only five studies to examine the effects of household migration on household fuel use directly. We briefly review them here.

We begin with Moran-Taylor and Taylor (2010) and Taylor et al. (2011), who report on a case study of a Mayan community in the Western Highlands of Guatemala where international migration to the US is common. These authors are interested in migrants as potential agents of change in the transition from firewood to cleaner fuels. Based on survey data collected from 102 households, they report that migrant households are more likely than non-migrant households to have an LPG stove or an improved woodburning stove, less likely to have a three-stone open fire or cook with wood most of the time, but nevertheless more likely to purchase firewood. These authors also comment on the importance of cultural preferences, which may change as the result of the ideas, behavior, and attitudes migrants bring home with them when they return, i.e., "social remittances." These two articles are the only ones to include return migration in their discussion of household fuel use, although its quantified effects on fuel use are not specifically assessed.

Qin (2010) focuses on the comparison of migrant and non-migrant households in Chongqing Municipality, Southwest China. Based on survey data collected in 345 
households in four villages, Qin (2010) finds that migrant households are less likely to use firewood and crop residue to satisfy their energy needs than non-migrant households ( $46 \%$ vs. 55\%, respectively). The study finds, however, that differences in fuel use are concentrated between non-migrant households involved in farming (62\%) and non-migrant households that were not (46\%). Whether local or distant, off-farm employment is the key to household fuel use in this setting. Migration matters, but as part of the larger context of decision-making. Because of high levels of out-migration, Chongqing Municipality is characterized by labor scarcity in relation to labor demand, with plentiful opportunities locally.

Hou et al. (2017) focus their study at the community level. They use data from the China Health and Retirement Longitudinal Survey (CHARLS) to describe correlates of fuel used for cooking in a representative sample countrywide. Although CHARLS is longitudinal, other than describing shifts in fuel use 2008-2012 in Gansu and Zhejiang Provinces, the authors rely on cross-sectional data from the 2011 wave. They examine correlations between the proportion of households using particular fuels (biomass, coal, clean fuels) and urbanicity, socioeconomic development, proximity to markets, fuel affordability, education, and one migration variable: the proportion of migrants from the community who are female. Hou et al. (2017) find a positive and significant correlation between this variable and the proportion of households using clean fuels, and a negative but insignificant correlation between it and the proportion of households relying on biomass. These results make sense considering how women are the primary fuelwood collectors in most developing countries (Kegode et al., 2017), and therefore, the number of working-age women in a household may have the greatest effect on the amount of labor available for fuelwood collecting (Link et al., 2012).

Gong's (2011) study moves beyond correlational analysis to specify multiple regression models of household fuel use. Based on data from a survey of 1074 rural households in Qinling Mountains of China, Gong (2011) finds a complex interaction between remittances, subjective poverty, and vulnerability such that the expected negative effect of remittances on per capita firewood consumption is substantially weakened in subjectively poor and vulnerable households. Gong's (2011) study represents an advance over previous ones in that it controlled for other household and community characteristics that might jointly affect migration and fuel use. However, like previous studies, it relies on cross-sectional data, inferring the effects of migration from differences in energy use between households with and without migrants rather than examining change in fuel use in relation to change in household membership due to migration.

The study by Manning and Taylor (2014) is the only one prior to ours to use longitudinal data. These authors use a formal economic approach to investigate the effects of migration on household fuel use in the context of rural Mexico 2002-2007 when the choice of interest was between collected firewood alone (used by virtually all households) and purchased LPG (which required a gas stove). Drawing on two waves of the Mexico National Rural Household Survey, involving approximately 3000 households, Manning and Taylor (2014) show that households having one or more migrants in the US spent less time collecting firewood, were more likely to have a gas stove, and spent more money on the purchase of LPG. Interestingly, the 
effect of migration depends on migrant destination. Having a migrant somewhere other than the US has no effect on patterns of fuel use, which the authors hypothesize is due to a lower likelihood and lesser average amount of remittances sent.

The Manning-Taylor (2014) study has many strengths, including the use of longitudinal data, careful attention to statistical identification, use of multiple modeling strategies, and tests of robustness. That said, although the authors do demonstrate the effect of migration on time spent collecting firewood-one of the channels through which migration affects fuel use (see Fig. 1) — they do not directly address the role of remittances in their analysis. Although they do control for household size, they do not consider migration in relation to other changes in household membership. Finally, they do not consider the potential effects of return migration, even though return migration from the US to Mexico was quite common at that time (Chort \& de la Rupelle, 2016; Massey et al., 2016).

We build on the literature in three ways. First, we embed the process of migration within household dynamics more generally. Households change as migrants leave and return but also as members die, new members are born, and others enter and exit with family changes such as marriage, separation/divorce, and widowhood. Households may also change in complexity as subfamilies are incorporated or break off. All of these changes are relevant to household labor allocation and to livelihood strategies in rural areas (Sherbinin et al., 2008; West, 2009). Yet, other than through controls for household size (e.g., Manning \& Taylor, 2014; also see Alem et al., 2016; Heltbert, 2004; Rahut et al., 2016), household changes are neglected in the literature on migration and fuel use.

Second, consistent with our interest in household dynamics, we view migration as a process, including both return and out-migration. The existing literature on this topic has focused almost exclusively on migrants departing from their household and has had little to say about return migrants. Yet, the success of migration as a livelihood strategy depends on migrants continuing to meet obligations to their home 'origin' household or returning when they meet an earnings target. Further, return migration potentially affects household fuel use through the same mechanisms as out-migration. Just as migrants may remit some part of their earnings, return migrants may bring earnings back with them. Similarly, just as migration reduces the availability of labor for firewood collection, return migration has the potential to restore it.

Finally, consistent with our interest in migration as a process, and especially in the context of household change, we draw on longitudinal data for our study. Longitudinal data enable us to describe and study real change, putting migration into the context of household change generally. It allows us to compare the effects of migration-related departures with departures due to other reasons (marriage, separation, divorce, and death), and to compare the effects of migrant returns with additions to the household through marriage, birth, and other processes. These comparisons help adjudicate between remittances and labor constraints as mechanisms for migration effects. These also suggest the important role of migration in effects of household size. Longitudinal data also strengthen causal inference as we are able to use statistical methods that focus on change and control for unobserved fixed characteristics of households and communities. 


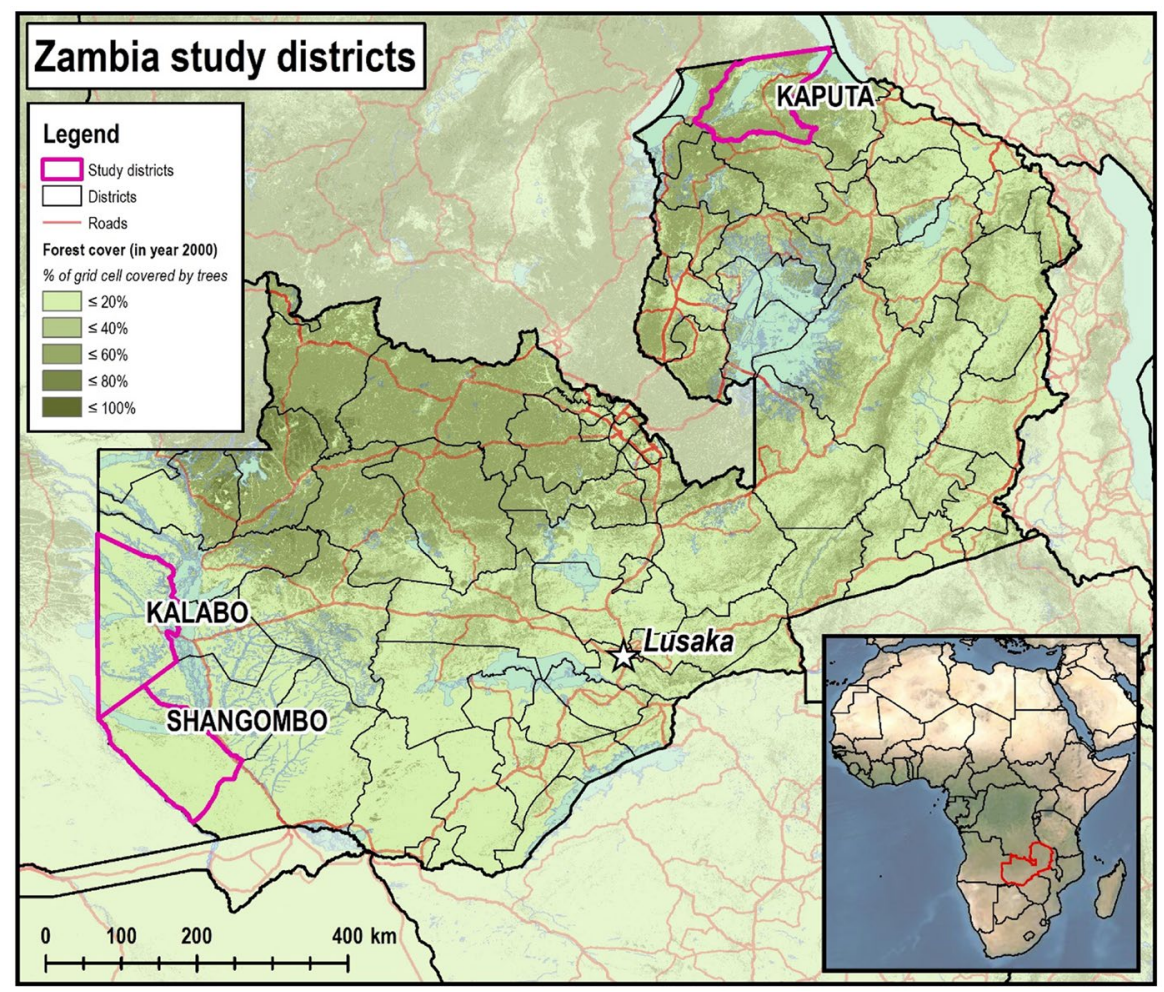

Fig. 2 Study area

\section{Data}

Our study is set in rural Zambia, a landlocked country in southern Africa that like many countries in the region has experienced rapid urbanization and rural-tourban migration over the last few decades (Hedlund \& Lundahl, 1983; Oucho \& Gould, 1993). During our study period, 2010 to 2017, Zambia experienced rapid economic growth averaging $6.5 \%$ of GDP per capita, which was driven largely by the mining industry. Most of this economic development was concentrated in urban areas and the Copperbelt, which drew migrants from rural areas. According to the most recent census, urban areas accounted for $39.5 \%$ of the population in 2010, up from $34.7 \%$ in 2000 (IOM 2019: 48). Net rural-urban migration explains this shift in population (Crankshaw \& Borel-Saladin, 2019).

Our study sites are located in three remote, rural districts at the periphery of the country: Kalabo and Shangombo districts in Western Province and Kaputa district in Northern Province (Fig. 2). These remote districts, among the poorest in Zambia, were largely excluded from rapid economic growth in recent decades (Siedenfeld \& Handa, 2011). Information about internal migration is not available at the district level, unfortunately, but at the provincial level, according to 2010 
census data, net migration was negative in these two provinces, -11.0 per 1000 in Northern Province and -8.1 per 1000 in Western Province (IOM, 2019: 470). Given their status as border provinces, it is possible that some out-migrants went to Angola (neighboring Western Province) or Democratic Republic of Congo (DRC, neighboring Northern Province), although at the national level, neither Angola nor DRC is in the top 10 destination countries for emigrants from Zambia (IOM, 2019: 24). Unfortunately, granular data on emigration from the study districts and provinces is lacking. ${ }^{2}$ However, even if cross-border migration were occurring, it would meet the conditions of a household strategy based on spatial diversification, which is that the economy at the place of destination be largely independent of that in the origin.

We draw on longitudinal data collected as part of an evaluation of Zambia's Child Grant Programme (CGP). The goal of the program was to reduce extreme poverty and the intergenerational transmission of poverty (Seidenfeld \& Handa, 2011). The CGP targets households with young children (under 5) living in districts characterized by extreme poverty and provides an unconditional cash transfer of 55,000 kwacha per month $(\sim \$ 1)$ to participating households (regardless of their size). In 2010, Zambia's Ministry of Community Development and Social Services rolled out the CGP in three districts: Kalabo, Shangombo, and Kaputa. These are some of the most remote and underdeveloped districts of the country, with poor infrastructure and child health outcomes. At that time, infant mortality was 97 per 1000 live births in these districts' two provinces, among the highest in Zambia (DHS, 2007).

A randomized control trial evaluation of the CGP was conducted by American Institutes of Research (AIR) and the University of North Carolina under contract to UNICEF. The selection of households followed a stratified multistage cluster design, with a random selection of villages within each of the three districts, followed by a random selection of eligible households within each of the selected villages. Eligibility was defined as the presence of a child under 3 years of age. Baseline data were collected in 2010, before households were randomized into and out of the CGP. We draw on the baseline data and follow-up surveys conducted in 2013, 2014, and 2017. Importantly, so as not to confound our results with the operation of the CGP itself (Chakrabarti, 2019; Mueller et al., 2020), we restrict our analysis to the 1085 households which were randomized to the control group and which had data from all four waves of data collection. ${ }^{3}$

\footnotetext{
2 There is likely not a strong economic pull for emigration to Angola or DRC given that employment opportunities over the past few decades have generally been far better in Zambia or other countries compared to less politically stable Angola and DRC (Cattaneo \& Robinson, 2019), and Zambian migrants would face significant language barriers working in formal sector jobs as Angola is Lusophone and DRC is Francophone.

3 The CGP evaluation includes 2515 households in the baseline, in which 1259 households were in the control group. The two study arms remained balanced over the survey waves as there was no differential attrition between treatment and control groups. For overall attrition, there are no statistically significant differences in baseline characteristics between the remaining sample at the follow-ups and the sample at baseline, indicating that samples did not change over time (an issue of external validity). Attrition was concentrated in the 24-month wave and focused in Kaputa district, where the drying up of Cheshi Lake forced households relying on the lake for fishing and farming to move. Among our tracked control group households, $3.0 \%$ moved from their original dwelling unit, and $2.3 \%$ moved out of the village.
} 
We focus on the use of fuel for cooking, which is the primary use of household energy in our study setting. For Zambia as a whole, the 2015 Living Conditions Monitoring Survey found that $83.6 \%$ of households use biomass fuel as their primary source for cooking; among rural households, biomass fuel use is nearly universal at $97.7 \%$, with $84.5 \%$ relying on firewood and $13.2 \%$ on charcoal as their primary source (Central Statistical Office, 2016). The rural households in our sample follow a similar pattern, as shown in Table 1. Firewood was the predominant choice, with almost all households (96.0\%) reporting use of firewood at baseline in 2010. Over the 7-year study period, there was a steady decline in reliance on firewood, from 96.0 to $88.7 \%$, while the use of charcoal as a primary fuel source almost quadrupled from 3.2 to $11.2 \%$. As a point of comparison, only about $1 \%$ of the households had access to electricity, and this changed little over the period.

The shift from firewood (a traditional and least efficient fuel) toward charcoal (a more efficient fuel) reflects the beginning of an energy transition (Heltberg, 2004). Previous studies have generally conceptualized the switch from inferior fuels to more advanced and cleaner fuels as moving up an "energy ladder." However, in our study villages, rather than moving away from inferior fuels completely, half of those using charcoal as their main fuel also used firewood for cooking. The percentage was even higher in 2017 after the prevalence of charcoal had tripled than in 2010. This reflects fuel stacking, where households diversify into different portfolios of energy sources at different points of the energy ladder (Van der Kroon et al., 2013). Unfortunately, it is too fine a cut to distinguish households that do and do not use firewood as a supplementary source among those whose main source is charcoal. Nor is it possible to distinguish the very few households using so-called modern fuels such as LPG and paraffin (collectively less than 1\%). In our analysis, we distinguish use of firewood from other fuels, and group other fuels such as LPG and paraffin that are uncommon in this setting with charcoal. Thus, we are asking what drivers shift households away from firewood as their main source of fuel for cooking, with particular attention to migration and other forms of household change.

We control for the influence of environmental characteristics in our analysis. To measure biomass availability, we use annual tree cover in 5-km buffers around individual households, which other authors have found to be the longest travel distance for collecting wood (Adkins et al., 2012; Brouwer et al., 1997; Jumbe \& Angelsen, 2011; Mlambo \& Huizing, 2004). ${ }^{4}$ This information is drawn from the Hansen Global Forest Change dataset (Hansen et al., 2013). As reported in Table 1, tree cover decreased slightly between 2010 and 2017. Given the possible influence of temperature and/or rainfall on household fuel use (Rawat et al., 2009; Shackleton et al., 2002), we also compile data on monthly precipitation and temperature from the Climatic Research Unit Time-Series Version 4.02 dataset. Table 1 shows the average precipitation and temperature in the survey month. The survey months are mainly in October and November, which falls during the hot and rainy season in Zambia. While there is little variation in temperature over waves of the survey, there

\footnotetext{
${ }^{4}$ We also test robustness lagging tree cover by 1 year; results are qualitatively similar and available upon request.
} 


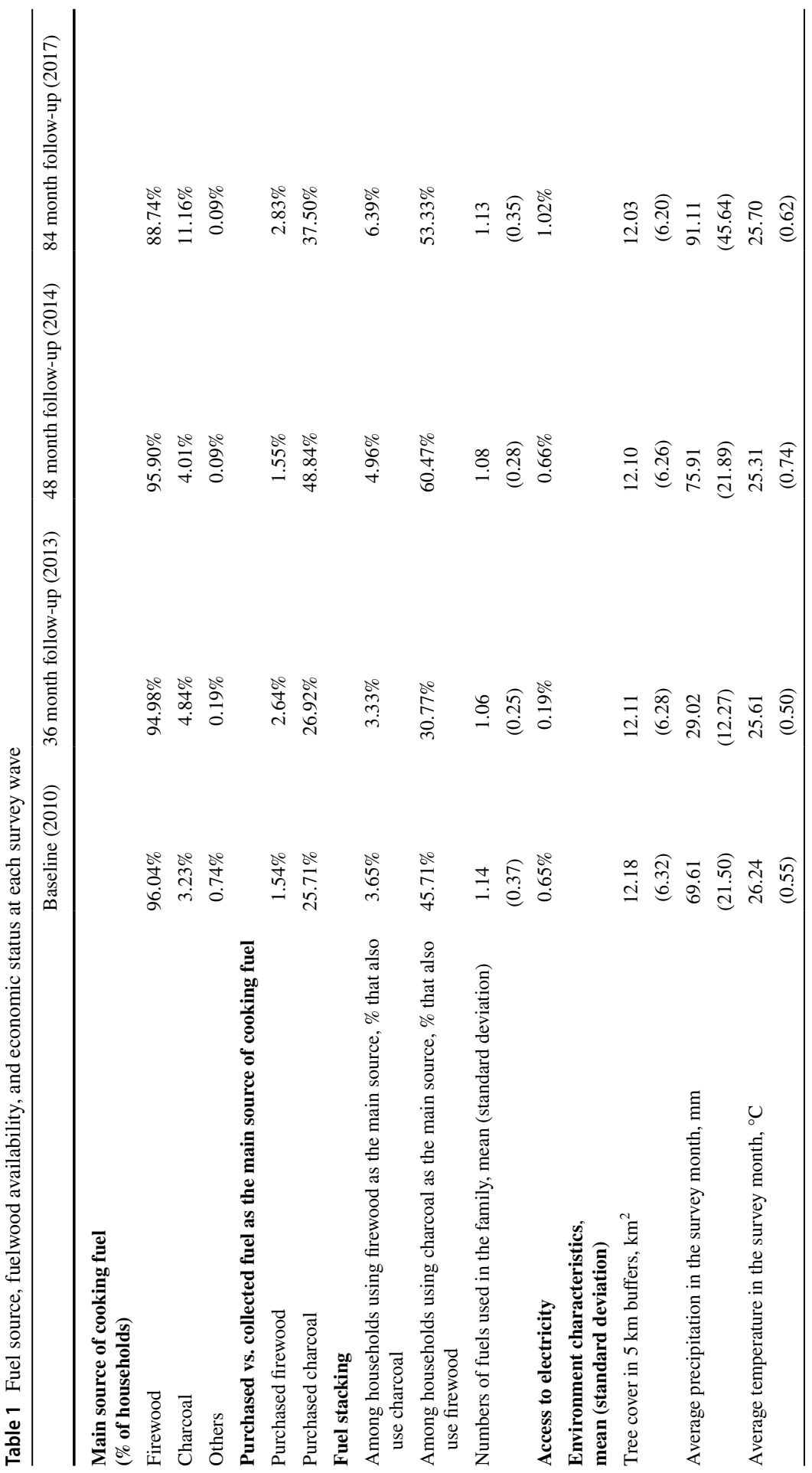




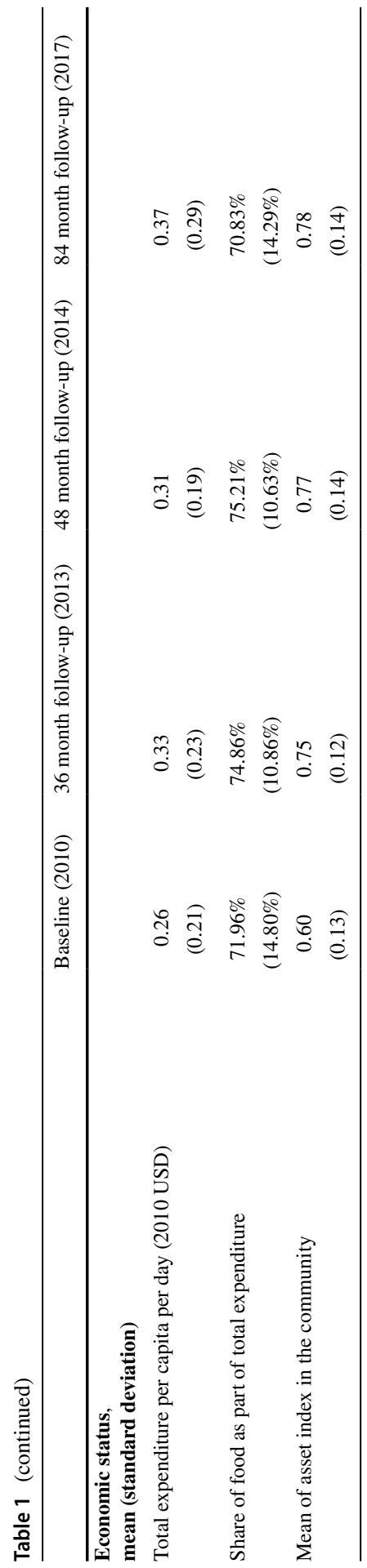


is substantial variability in precipitation. In 2013, mean precipitation was $29.02 \mathrm{~mm}$ in the survey month, a low point, ranging up to a high of $91.11 \mathrm{~mm}$ in 2017 . To deal with skewed distributions or extreme values, we apply the Inverse Hyperbolic Sine (IHS) transformation ${ }^{5}$ to the three environment variables in the regression analysis.

Table 1 also presents information about household economic status over waves. Daily expenditure per capita increased by almost half between 2010 and 2017, consistent with the overall growth experienced in Zambia during this period. Despite these improvements, however, these are still extremely poor households. The average expenditure per capita per day is about US\$0.32; as a point of reference, the international poverty line is US\$1.90 (Ferreira et al., 2016). Since income is a mediator of the effects of migration on fuel use, the inclusion of income in regressions would control away the processes of interest. Thus, we instead control for community level economic status with the mean community asset index ${ }^{6}$ (Handa et al., 2018), which increased by $51 \%$ between 2010 and 2017 .

We now turn to the determinants of chief interest: household size and change. This information was derived from detailed household rosters collected at baseline and updated at each subsequent wave of data collection. Of particular interest are changes between waves, and indeed, as shown in Table 2, households change quite a bit. Considerable movement into and out of households characterizes each intersurvey interval, with the amount depending in part on the width of the interval, although departures consistently exceed arrivals by a substantial margin. Among departures (aside from deaths), no matter the survey interval, most individuals move locally within the same or to a nearby village, and fewer to a more distant town, city, or the capital city Lusaka. The numbers of males and females departing the household are approximately equal. New members largely consist of births. The number of return migrants is quite small but increased over the study periods, from 0.005 in 2013 to 0.09 in 2017. Reflecting the cumulating effect of departures from households that were not fully counterbalanced by entries, the total count of household members (that was unchanged since the previous wave of data collection) declined from 6.14 in 2013 to 5.94 in 2017 . Households do not report receiving remittances very often ( $1.9 \%$ of households on average), although it is possible that migrants brought money with them when they returned (Piotrowski \& Tong, 2010). Overall, with return migration and remittances relatively rare, CGP communities appear to fall within a broader established pattern of rural-urban migration (Massey, 1990).

\footnotetext{
${ }^{5}$ The inverse hyperbolic sine (IHS) is a transformation that is defined for all values, including negative and zero (Burbidge \& Magee, 1988):

$$
\ln \left(\theta D_{i t}+\left(\theta^{2} D_{i t}^{2}+1\right)^{\frac{1}{2}}\right) / \theta=\sinh ^{-1}\left(\theta D_{i t}\right) / \theta
$$

where $\theta=1$ in our transformation and the inverse sine is approximately equal to $\ln \left(2 D_{i t}\right)$, except for small value (e.g., less than 1), so it can be interpreted in the same way as a natural logarithmic transformation (Friedline et al., 2015; Pence, 2006).

${ }^{6}$ This index is based on productive assets. We checked robustness by comparing results with those found with a domestic asset index and a livestock asset index. Results (available on request) are qualitatively similar and consistent.
} 


\section{Empirical strategy}

Our analysis focuses on the potential effects of migration and other changes in household size and composition on fuel use. We model fuel use with a binary variable, which equals 1 if firewood is the main source of cooking fuel for the household, and 0 otherwise. While Logit or Probit models have been widely used to estimate binary variables, these nonlinear probability models (NLPMs) can suffer difficulties of interpretation. Logit, Probit, or other NLPMs do not separately identify the mean and variance, and thus when comparing coefficients within the same model, interpretations will be determined by the assumptions upon which the model is based (Breen et al., 2018; Cameron \& Heckman, 1998). They also create problems for comparisons of coefficients across different models, as the residual standard deviations of the models differ (Allison, 1999; Breen et al., 2014, 2018; Karlson et al,. 2012; Mood, 2010). Therefore, we use the linear probability model (LPM), which is preferable to the Logit or Probit models when the purpose is to compare and interpret coefficients within and between models (Breen et al., 2018). We take a fixed effects approach, which avoids the problem of heterogeneity bias and controls out time-invariant variables, both those that are observable and those that are not (Allison, 2009).

One concern in obtaining consistent estimates is the potential endogeneity of migration variables. Some previous studies have pointed out the possibility of reverse causality if prior fuel use affects fuel availability, and fuel availability in turn drives migration (Manning \& Taylor, 2014). We do not believe that is the case for our study. As shown in Table 1, the amount of tree cover within $5 \mathrm{~km}$ of each survey household is fairly steady over the survey years, which is not what we would expect if fuel use were driving fuel availability. We also tested whether tree cover within 5 $\mathrm{km}$ was less for migrant than non-migrant households and found no significant difference. ${ }^{7}$ We do, of course, control for the effect of firewood availability on fuel use.

Even though reverse causality seems very unlikely, we are nevertheless concerned about potential endogeneity because of the possibility that households make joint decisions about labor allocated to fuel collection and migration. This joint decisionmaking might involve any or all of the migration variables of interest: local moves, long-distance moves, remittances, and returns. We test the endogeneity of the migration variables using an instrument variable (IV) approach, using two instruments for each migration variable: the community mean of the migration variable and the interaction between the community mean and tree cover within a 5-km buffer of household in the baseline. We employ a two-stage least squares (2SLS) model followed by a Durbin-Wu-Hausman test. In our analysis, the Durbin-Wu-Hausman test rejects the exogeneity of the migration variables (Appendix Table 4). Further, F-tests conducted for the instrumental variables in the first stage of estimation suggest nonweak instruments (Appendix Table 5). Therefore, IV estimates are preferred.

\footnotetext{
7 Two-sample $t$ test (unequal variances) is performed under the null hypothesis that the difference between tree cover around migrant households and tree cover around non-migrant households is greater than zero. $p$ values are greater than 0.9 for the 3 tests in each follow-up year.
} 
Table 2 Household demographic characteristics at each survey wave

\begin{tabular}{|c|c|c|c|c|}
\hline & \multicolumn{4}{|c|}{ Mean (standard deviation) } \\
\hline & $\begin{array}{l}\text { Baseline } \\
(2010)\end{array}$ & $\begin{array}{l}36 \text { month } \\
\text { follow-up } \\
(2013)\end{array}$ & $\begin{array}{l}48 \text { month } \\
\text { follow-up } \\
\text { (2014) }\end{array}$ & $\begin{array}{l}84 \text { month } \\
\text { follow-up (2017) }\end{array}$ \\
\hline Number of departing members ${ }^{a}$ & & $\begin{array}{l}0.43 \\
(1.11)\end{array}$ & $\begin{array}{l}0.70 \\
(1.33)\end{array}$ & $\begin{array}{l}1.12 \\
(1.61)\end{array}$ \\
\hline Number of local movers & & $\begin{array}{l}0.24 \\
(0.80)\end{array}$ & $\begin{array}{l}0.35 \\
(0.99)\end{array}$ & $\begin{array}{l}0.48 \\
(1.01)\end{array}$ \\
\hline Number of local movers within the same village & & $\begin{array}{l}0.05 \\
(0.33)\end{array}$ & $\begin{array}{l}0.11 \\
(0.59)\end{array}$ & $\begin{array}{l}0.15 \\
(0.48)\end{array}$ \\
\hline Number of local movers to nearby village & & $\begin{array}{l}0.19 \\
(0.71)\end{array}$ & $\begin{array}{l}0.24 \\
(0.78)\end{array}$ & $\begin{array}{l}0.34 \\
(0.85)\end{array}$ \\
\hline Number of long-distance movers (migrants) & & $\begin{array}{l}0.14 \\
(0.60)\end{array}$ & $\begin{array}{l}0.23 \\
(0.74)\end{array}$ & $\begin{array}{l}0.37 \\
(0.93)\end{array}$ \\
\hline Number of deaths & & $\begin{array}{l}0.03 \\
(0.17)\end{array}$ & $\begin{array}{l}0.11 \\
(0.38)\end{array}$ & $\begin{array}{l}0.26 \\
(0.57)\end{array}$ \\
\hline Number of male departing members & & $\begin{array}{l}0.21 \\
(0.64)\end{array}$ & $\begin{array}{l}0.36 \\
(0.82)\end{array}$ & $\begin{array}{l}0.58 \\
(1.01)\end{array}$ \\
\hline Number of female departing members & & $\begin{array}{l}0.22 \\
(0.63)\end{array}$ & $\begin{array}{l}0.35 \\
(0.75)\end{array}$ & $\begin{array}{l}0.53 \\
(0.91)\end{array}$ \\
\hline Number of other departing members ${ }^{b}$ & & $\begin{array}{l}0.29 \\
(0.91)\end{array}$ & $\begin{array}{l}0.47 \\
(1.08)\end{array}$ & $\begin{array}{l}0.74 \\
(1.18)\end{array}$ \\
\hline Number of new members ${ }^{\mathrm{c}}$ & & $\begin{array}{l}0.07 \\
(0.30)\end{array}$ & $\begin{array}{l}0.27 \\
(0.57)\end{array}$ & $\begin{array}{l}0.58 \\
(0.86)\end{array}$ \\
\hline Number of return migrants & & $\begin{array}{l}0.005 \\
(0.07)\end{array}$ & $\begin{array}{l}0.07 \\
(0.31)\end{array}$ & $\begin{array}{l}0.09 \\
(0.31)\end{array}$ \\
\hline Number of new births & & $\begin{array}{l}0.05 \\
(0.21)\end{array}$ & $\begin{array}{l}0.14 \\
(0.37)\end{array}$ & $\begin{array}{l}0.38 \\
(0.57)\end{array}$ \\
\hline Number of other new members ${ }^{\mathrm{d}}$ & & $\begin{array}{l}0.02 \\
(0.19)\end{array}$ & $\begin{array}{l}0.06 \\
(0.32)\end{array}$ & $\begin{array}{l}0.11 \\
(0.53)\end{array}$ \\
\hline Number of members unchanged since the last wave $\mathrm{e}^{\mathrm{e}}$ & $\begin{array}{l}5.66 \\
(2.04)\end{array}$ & $\begin{array}{l}6.14 \\
(2.19)\end{array}$ & $\begin{array}{l}6.01 \\
(2.12)\end{array}$ & $\begin{array}{l}5.94 \\
(2.18)\end{array}$ \\
\hline Presence of remittances & & $\begin{array}{l}0.01 \\
(0.08)\end{array}$ & $\begin{array}{l}0.02 \\
(0.14)\end{array}$ & $\begin{array}{l}0.03 \\
(0.17)\end{array}$ \\
\hline Household head age & $\begin{array}{l}29.70 \\
(9.49)\end{array}$ & $\begin{array}{l}32.91 \\
(9.75)\end{array}$ & $\begin{array}{l}33.93 \\
(9.92)\end{array}$ & $\begin{array}{l}36.60 \\
(9.56)\end{array}$ \\
\hline
\end{tabular}

${ }^{a}$ The number of departing members in household counts all leaving people since the baseline. It was decomposed into local movers, long-distance movers (migrants), and deaths. Discrepancies between the number of departing members and the sum of movers and deaths in year 2013 and 2014 are due to different response rates in the corresponding survey questions

${ }^{\mathrm{b}}$ The number of other departing members counts all leaving people except long-distance movers (migrants)

${ }^{\mathrm{c}}$ The number of new members in household is measured between the current wave and one lagged wave

${ }^{\mathrm{d}}$ The number of other new members counts all new entering people except new births and return migrants

eIn the baseline, the number of "same members since the last wave" measures household size 
Our fixed-effects linear probability model with two-stage least square estimators can be written as:

$$
\begin{aligned}
& M^{o}{ }_{i t}-\bar{M}_{i}^{o}=\sum_{k=1}^{k} \beta_{j}\left(z^{o}{ }_{i t k}-\bar{z}_{i k}^{o}\right)+\left(\varepsilon^{o}{ }_{i t}-\bar{\varepsilon}_{i}^{o}\right) \\
& M^{r}{ }_{i t}-\bar{M}_{i}^{r}=\sum_{k=1}^{k} \beta_{j}\left(z_{i t k}^{r}-\bar{z}_{i k}^{r}\right)+\left(\varepsilon_{i t}^{r}-\bar{\varepsilon}_{i}^{r}\right) \\
& H^{d}{ }_{i t}-\bar{H}^{d}{ }_{i}=\sum_{k=1}^{k} \beta_{j}\left(z^{d}{ }_{i t k}-\bar{z}^{d}{ }_{i k}\right)+\left(\varepsilon^{d}{ }_{i t}-\bar{\varepsilon}^{d}{ }_{i}\right) \\
& F_{i t}-\bar{F}_{i}=\beta_{1}\left(\widehat{M^{o}{ }_{i t}}-\widehat{\overline{M^{o}}}\right)+\beta_{2}\left(\widehat{M^{r}}{ }_{i t}-\widehat{M^{r}}{ }_{i}\right) \\
& \left.+\beta_{3} \widehat{\left(H^{d}\right.}{ }_{i t}-\widehat{H^{d}}{ }_{i}\right) \\
& +\beta_{4}\left(H^{e}{ }_{i t}-\overline{H^{e}}{ }_{i}\right) \\
& +\sum_{j=5}^{j} \beta_{j}\left(x_{i t j}-\bar{x}_{i j}\right)+\left(\varepsilon_{i t}-\bar{\varepsilon}_{i}\right)
\end{aligned}
$$

where $F_{i t}$ is a binary variable reflecting fuel use, $M^{o}{ }_{i t}$ represents number of outmigrants, $M^{r}{ }_{i t}$ represents number of return migrants, $H^{d}{ }_{i t}$ represents other departures from the household, $H^{e}{ }_{i t}$ represents other entrants to the household, $z_{i t}$ represents instruments for migration variables, $x_{i t j}$ represents time-variant controls for household $\underline{i}$ in timet, and year fixed effects. $\varepsilon_{i t}$ represents the residuals. $F_{i}, M^{o}{ }_{i}, M^{r}{ }_{i}, H^{d}{ }_{i}, H^{e}{ }_{i}, \bar{x}_{i j}$, and $\bar{\varepsilon}_{i}$ represent household $i$ 's mean across all years, which account for the between-household effects. $\left(F_{i t}-\bar{F}_{i}\right),\left(M^{o}{ }_{i t}-\bar{M}^{o}{ }_{i}\right),\left(M^{r}{ }_{i t}-\bar{M}^{r}{ }_{i}\right),\left(H^{d}{ }_{i t}-\bar{H}^{d}{ }_{i}\right),\left(H^{e}{ }_{i t}-\bar{H}^{e}{ }_{i}\right)$, $\left(x_{i t j}-\bar{x}_{i j}\right)$, and $\left(\varepsilon_{i t}-\bar{\varepsilon}_{i}\right)$ measure variation within individual households over time, which account for the within-household effects. Considering the heteroskedasticity that arises with the LPM (Breen et al., 2018) as well as the clustered nature of the sample, we estimate robust standard errors (also known as the sandwich estimators), which are clustered at the community level.

Building on our arguments, and consistent with the specifics of the case, we advance the following hypotheses about the coefficient estimates in the equation above: (1) $\beta_{1}$ is negative, and out-migrants will decrease the use of firewood, 
especially migrants to distant (likely urban) places; (2) $\beta_{2}$ is ambiguous, resulting from the balance of the positive effects of return migrants through increased labor supply and the negative effects of possible financial resources brought home; (3) $\beta_{3}$ is negative, as other departures from the household will decrease the use of firewood; (4) $\beta_{4}$ is positive, as other entrants to the household may increase the use of firewood, although this depends on the relative number of births to adults.

\section{Results}

Table 3 reports average marginal effects of migration and other changes in household membership on the probability of firewood use. There are nine model specifications. The first examines the effect of net change in household size on fuel use. Subsequent specifications decompose that change in a variety of ways, by distinguishing exits from entries and then furthermore by distinguishing different types of exits (migration, death, and other household change) and entries (births, return migration, and other household change). One specification differentiates male and female entries and exits. These decompositions enable us to measure the effect of migration on fuel use in the context of household change, to consider return as well as out-migration, and to compare the effects of migration to other changes in household membership. A final specification examines the effect of remittances, although as we have noted, very few households report receiving them. In each specification, we control for the number of household members that did not change from the previous wave, the age of household head, tree cover, electricity access, community assets, precipitation, temperature, and year fixed effects.

As shown in model (1) of Table 3, a net increase in household size increases the probability of using firewood by a statistically significant margin. Decomposing this change into exits and entries in model (2) leads to strong and significant negative effects for departing members, but weak and non-significant effects for new members. This means that households losing fewer members are more likely to use firewood for cooking than those who lose more members. Models (3) through (6) explore which household exits are responsible for this effect. Differentiating migrants who moved to distant (likely urban) places from other exits from the household in model (3) shows significant negative effects for both. Model (4) decomposes these other exits into local movers (same or nearby village), more distant migrants, and deaths. It shows significant negative effects for all three categories of exit, although the effect of deaths is weaker. Model (5) further differentiates local movers into those moving within the village and those moving to a nearby village. Estimates for this model reveal no effect of movement within the local community on the use of firewood for cooking, but significant negative effects for other 


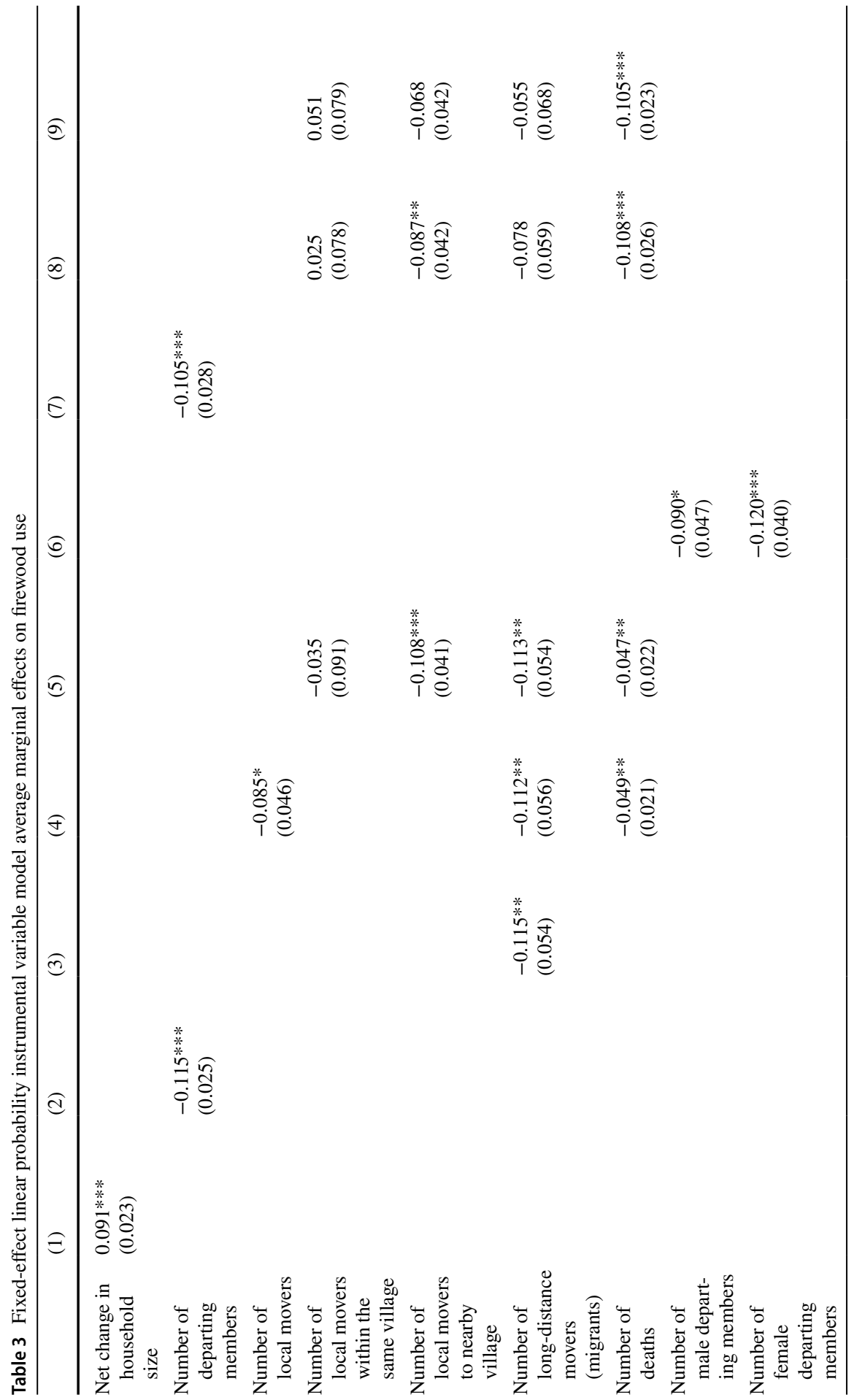




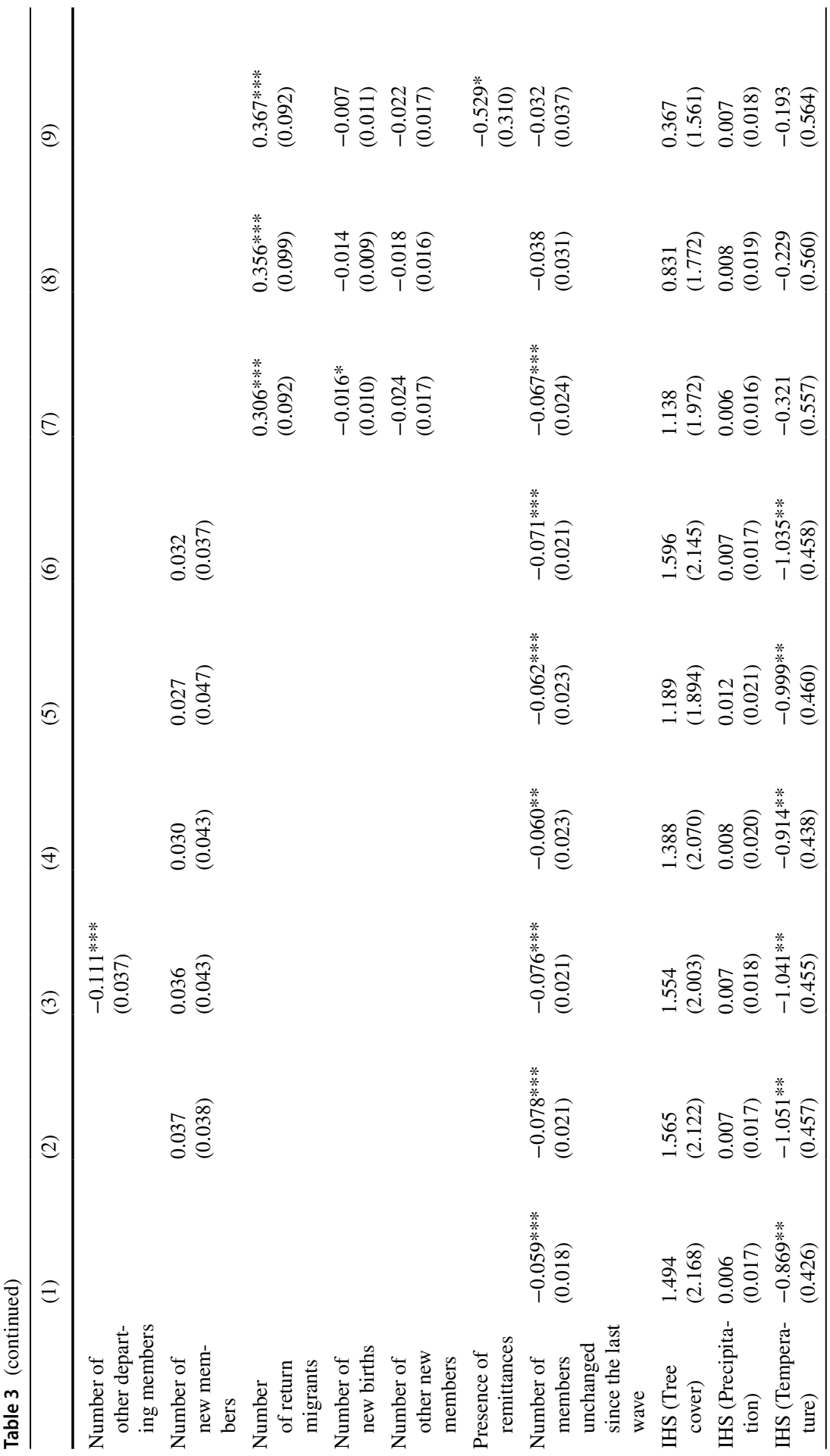




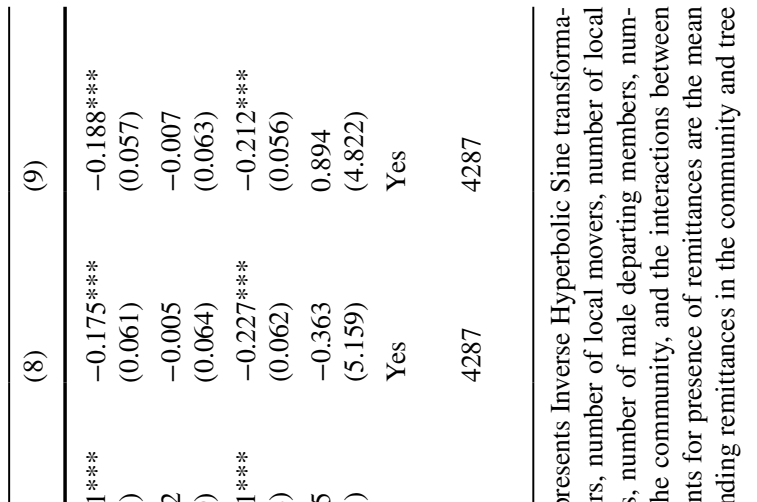

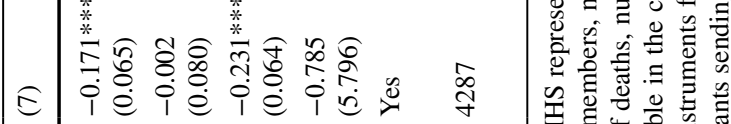

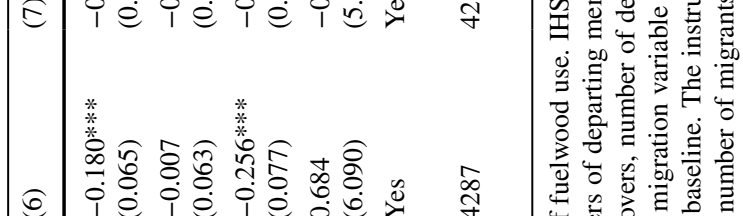

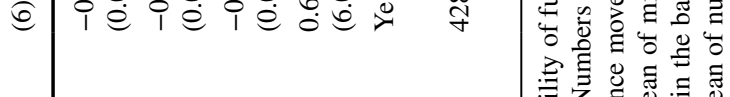

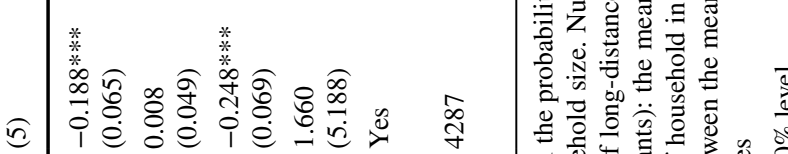

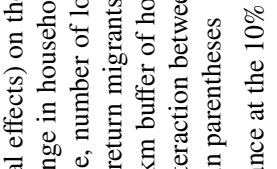

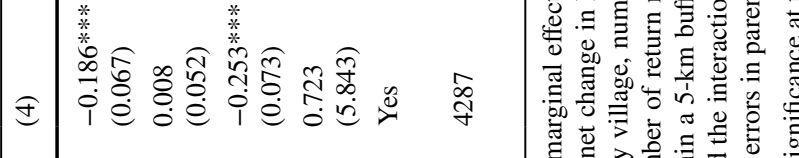

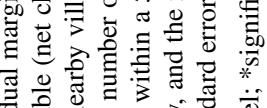

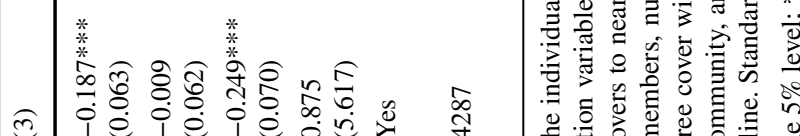

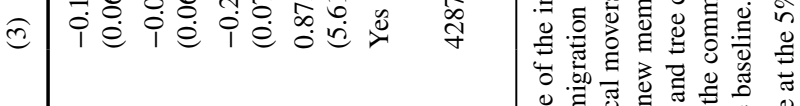

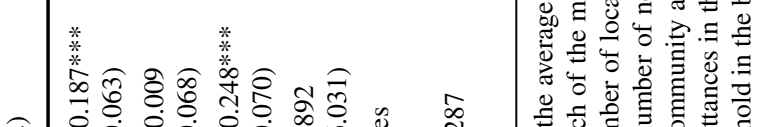

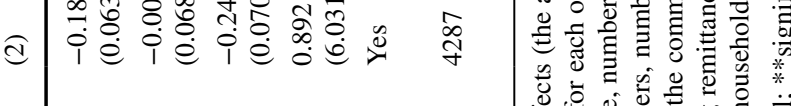

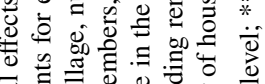

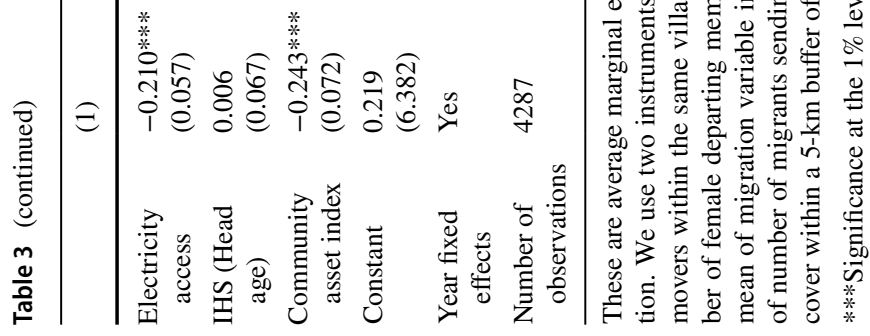


household exits. When household members move away, whether it is to other rural villages or to more distant urban locations, the likelihood that households use firewood decreases by about 10 percentage points. Given that women in LMICs such as Zambia are often responsible for firewood collection, model (6) divides departures into male and female. The estimated effect of the number of females who leave is greater than the effect of males leaving, as we might expect, but the two effects do not differ significantly from each other.

Consistent with our hypothesis, the results suggest that when members move out of the village, households are more likely to shift away from firewood as a primary source for cooking. Two different mechanisms could be responsible: (1) the loss of productive labor or (2) increases in income through remittances. The importance of the first mechanism is suggested by roughly equivalent effects for local and longerdistance moves, in combination with no effect for moves within the village. Longerdistance migrants are more likely to be in the urban labor market and get better payment from off-farm employment. Local migrants are more likely to be working as agricultural day laborers, generally making less money (if paid in cash) than longerdistance migrants in urban areas. Thus, the probability of sending back remittances and the amount of remittances would both be larger for long-distance migrants. However, we do not see a stronger effect for longer-distance migrants, suggesting that the importance of the labor supply mechanism. Further corroboration is offered by the null effect of household members moving within the same village, where they can easily help the origin household if needed, thus releasing the labor constraint.

Turning now to household entries, model (7) decomposes them into births, returned migrants, and other entries. Among these, returned migrants have a strong and significant positive effect on the use of firewood for cooking. This strong effect must be understood in relation to the relative rarity of return migration in the GCP communities. While returned migrants may bring resources and cash back with them, they also contribute to the household labor force. With more labor available to collect firewood, the household is more likely to use firewood as the main source of cooking. Referencing our hypothesis, the results suggest that returned migrants affect fuel use mainly through the mechanism of labor allocation in this setting.

Support for both the labor availability and income hypotheses can be found in model (9), which includes a measure for remittances. If remittances were responsible for the effect of migration on fuel use, we would expect to see a decrease in the use of firewood and further, as a potential mediator, to see the effects of the migration variables weaken. As shown in model (9), the effect of remittances on firewood use is negative and marginally significant. The estimated effects of the return migration do not change with its inclusion, but the effects of out-migration, both local and longer distance, weaken and lose statistical significance. This pattern of results suggests that labor allocation is the dominant mechanism relevant to the effects of return migration on fuel use, but for out-migration, the remittance mechanism dominates. However, we want to be careful to not overinterpret these results, as the effect 
of remittances is only marginally significant and the number of households receiving remittances is very small.

With respect to control variables, the count of members unchanged since the last wave has significantly negative effects in models (1)-(7). This may reflect changing household composition as members leave. GCP households are labor-constrained. Those remaining in the household when productive members leave are likely to be young children or elders unable to contribute as much to household tasks. Tree cover in 5-km buffers has a positive but insignificant effect, which suggests that fuelwood availability is not a key determinant of household reliance on firewood in our setting. Precipitation also does not affect firewood use, but average temperature (in the survey month) does: increases in temperature decrease firewood use. Electricity accessibility also makes a difference, as once a household gains access to electricity, it is less likely to use firewood as its main cooking fuel. This is consistent with the findings in the existing literature, although as noted earlier, very few GCP households have access to electricity. Finally, as shown in the significant negative effect of the asset index, households in wealthier communities are less likely to rely on firewood for cooking than those in less well-off communities.

\section{Conclusion}

Our study is the first to model the dynamic effects of migration on household fuel use in sub-Saharan Africa. We leveraged intra-household variation in household membership over time and the use of firewood as a primary cooking fuel in an analysis based on panel data collected in three districts of rural Zambia. Whereas previous studies have largely relied on comparisons between households with and without migrants for their inferences, we looked instead at how individual households respond when one of their members migrates. Our fixed-effects analyses suggest that out-migration helps move households away from traditional fuels toward more modern fuels, while return migration moves them in the opposite direction. Remittances, although rare in our setting, encourage more modern fuel use.

Importantly, we considered migration as a process. Whereas prior studies restricted their attention to out-migrants only, our study also took account of possible return migrants. Both are potentially relevant to fuel use. Just as out-migration may increase labor constraints, making firewood collection more difficult, return migration may ease them. Both affect fuel use in rural Zambia, according to our results, although return migration is uncommon. Furthermore, they are linked; the success of migration as a livelihood strategy depends on migrants continuing to view themselves as members of and obligated to their original household, contributing to its welfare through remittances, and possibly returning once they have reached their earnings target. Migration does not help to move households away from traditional fuels permanently in this setting, at least not yet. It is possible that when the payoff 
to origin households in the form of remittances and the return of migrants who are target earners is fully realized that effects on household fuel use will shift.

Finally, migration can affect fuel use both through its implications for labor allocation and through its implications for remittances. To the extent that labor allocation is the explanation, then other changes in household size and composition should have similar effects as migration. To the extent that it is income, then remittances should have an effect on fuel use. The results of our analysis suggest that both play a role in this setting. We find direct and indirect evidence for the importance of labor availability. First, the estimated effects of long-distance out-migration are about the same as the estimated effects of shorter-distance migration. The similarity of effects indicates the importance of labor supply given that long-distance out-migration is expected to generate more income. Further corroboration is found in the negative effects of other departures from the household. Second, the effect of return migration is positive, consistent with a relaxed household labor constraint, rather than negative, reflecting a possible income effect. These results are important for studies of energy poverty generally, as differences in household size and changes over time occur for many reasons potentially relevant to household fuel use. Evidence regarding remittances is direct: although relatively uncommon, households receiving remittances are less likely to use firewood for cooking.

Our analysis and results are consistent with the fact that the cost of labor for collecting fuel is greater than the cost of purchasing fuel in our study region. Gathering firewood incurs a non-trivial opportunity cost to the household. From the last survey wave in 2017, the cost of time/labor to collect fuel per 4 weeks is $67.7 \mathrm{ZMW}$ for adults (45.15 ZMW for children) based on the average amount of time spent gathering firewood as reported by households, and the local wage. Meanwhile expenditure on fuel in the 4-week reference period from the survey data is $46.7 \mathrm{ZMW}$. If we account for the transaction cost of purchasing fuel which is dominated by transportation cost to market, 5.5 ZMW (travel time to market multiplied by adult average hourly wage), the total cost of purchasing fuel is $52.2 \mathrm{ZMW}$. The opportunity cost of labor for collecting fuel is still greater than the cost of purchasing fuel. Thus, we expect households to shift from collected firewood to purchased fuel when they face a tighter labor constraint and looser budget constraint.

It is important that these results be replicated in different settings and among different populations. First, the three districts represented in this study are remote and underdeveloped, examples of extreme poverty. Our results are thus most generalizable to similar contexts in rural sub-Saharan Africa. The particular tradeoff of labor availability and remittance effects associated with migration may not generalize to less-remote settings where migration is less costly due to well-established migration streams and infrastructure connecting rural to urban areas. It also may not generalize to places with a better developed local economy, including off-farm employment opportunities (cf. Gong, 2011; Wang et al., 2012). Second, the households used in our analysis were selected based on eligibility for the Child Grant Programme, 
defined as the presence of a child under three. Our study thus captures households at a particular moment in the life course characterized by labor constraints, and so the availability of labor for firewood collection may be especially important in these households. Finally, it appears that patterns of rural-urban migration are only just beginning to become established in these remote parts of rural Zambia. The consequences for origin households and home communities may change as out- and especially return migration become more common.

These caveats notwithstanding, our study contributes to the literature on determinants of household energy use, providing evidence that migration affects households' fuel choices in the context of extreme poverty. Improving access to more efficient sources of energy for poor households in developing countries has been a major challenge for global development. While efforts in promoting the transition to cleaner, more modern energy sources have been increasing, there remain questions about which approaches are the most effective at reducing energy poverty. Although the marginal effects of improvement of electricity access on cleaner fuel adoption are great, the electricity access rates have been extremely low in our context. Ruralurban migration is an increasingly salient phenomenon in this country and one of the most widespread and defining features of demographic changes in the Global South today. Our results suggest a role for migration in this transition, particularly out-migration. We expect this finding has implications in broad areas of sub-Saharan Africa, where most rural and poor urban households depend on biomass for their cooking needs (IEA, 2019).

Acknowledgements We acknowledge Ms. Kate Brandt, Mr. Brian Frizzelle, and Mr. Varun Goel for coding assistance on processing geospatial variables. We appreciate comments and insights from Dr. Pamela Jagger, Dr. Erin Sills, and Dr. Cheryl Weyant and the audience at the EPPSA seminar and CPC Interdisciplinary Population Science Seminar.

Funding This work received direct support from the National Science Foundation [PIRE-1743741] and general support from the National Institutes of Health to the Carolina Population Center [NICHD P2C HD050924]. The household survey data used were collected by the American Institutes of Research and the University of North Carolina under contract to UNICEF-Zambia.

\section{Appendix}

Table 4 Durbin Wu-Hausman test for endogeneity of migration variables

\begin{tabular}{llllllllll}
\hline & $(1)$ & $(2)$ & $(3)$ & $(4)$ & $(5)$ & $(6)$ & $(7)$ & $(8)$ & $(9)$ \\
\hline F-statistics & 13.74 & 8.43 & 5.55 & 2.72 & 2.87 & 5.07 & 28.16 & 14.48 & 14.49 \\
$p$ value & 0.0006 & 0.0008 & 0.0025 & 0.0556 & 0.0337 & 0.0042 & 0.0000 & 0.0000 & 0.0000 \\
\hline
\end{tabular}




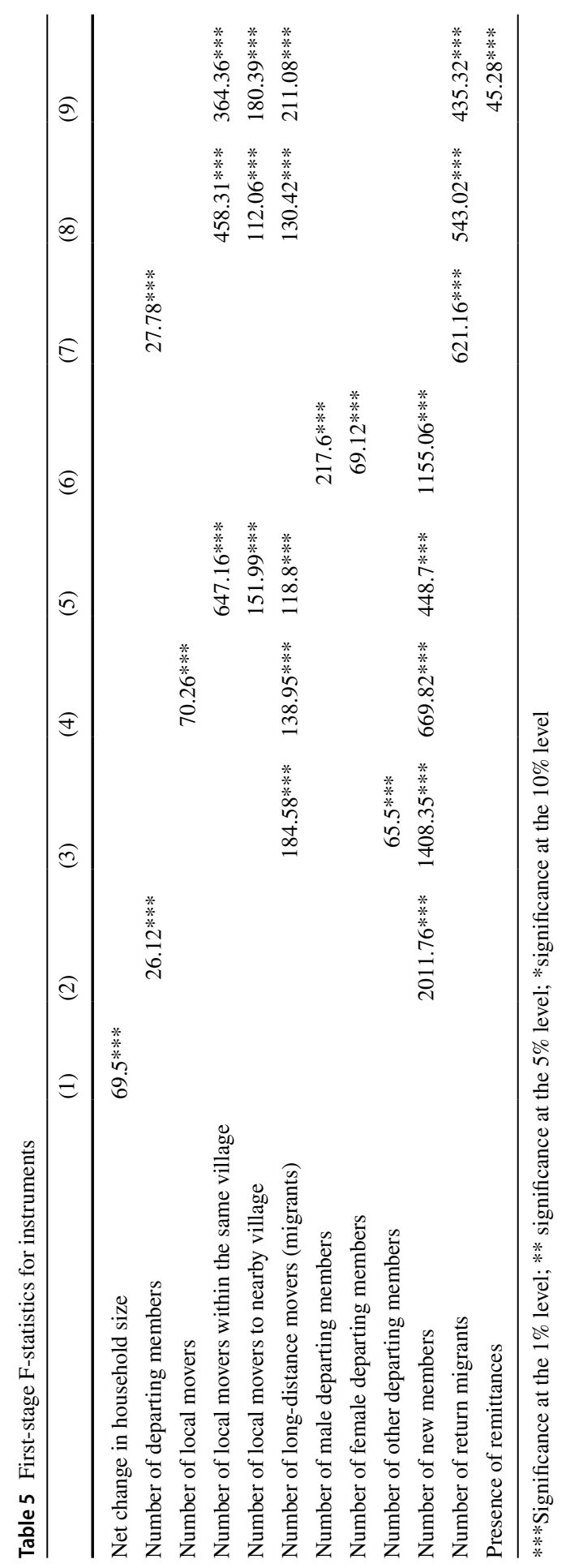


Open Access This article is licensed under a Creative Commons Attribution 4.0 International License, which permits use, sharing, adaptation, distribution and reproduction in any medium or format, as long as you give appropriate credit to the original author(s) and the source, provide a link to the Creative Commons licence, and indicate if changes were made. The images or other third party material in this article are included in the article's Creative Commons licence, unless indicated otherwise in a credit line to the material. If material is not included in the article's Creative Commons licence and your intended use is not permitted by statutory regulation or exceeds the permitted use, you will need to obtain permission directly from the copyright holder. To view a copy of this licence, visit http://creativecommons.org/licenses/ by $/ 4.0 \%$.

\section{References}

Adelekan, I. O., \& Jerome, A. T. (2006). Dynamics of household energy consumption in a traditional African city. Ibadan. Environmentalist, 26(2), 99-110. https://doi.org/10.1007/s10669-006-7480-2

Adkins, E., Oppelstrup, K., \& Modi, V. (2012). Rural household energy consumption in the millennium villages in sub-Saharan Africa. Energy for Sustainable Development, 16(3), 249-259. https://doi. org/10.1016/j.esd.2012.04.003

Alem, Y., Beyene, A. D., Köhlin, G., \& Mekonnen, A. (2016). Modeling household cooking fuel choice: a panel multinomial logit approach. Energy Economics, 59, 129-137. https://doi.org/10.1016/j. eneco.2016.06.025

Allison, P. D. (2009). Fixed effects regression models (Vol. 160). SAGE publications.

Allison, P. D. (1999). Comparing logit and probit coefficients across groups. Sociological methods \& research, 28(2), 186-208.

Aunan, K., \& Wang, S. (2014). Internal migration and urbanization in China: Impacts on population exposure to household air pollution (2000-2010). Science of The Total Environment, 481, 186-195. https://doi.org/10.1016/j.scitotenv.2014.02.073

Breen, R., Karlson, K. B., \& Holm, A. (2018). Interpreting and understanding logits, probits, and other nonlinear probability models. Annual Review of Sociology, 44, 39-54.

Breen, R., Holm, A., \& Karlson, K. B. (2014). Correlations and nonlinear probability models. Sociological Methods \& Research, 43(4), 571-605.

Brouwer, I. D., Hoorweg, J. C., \& van Liere, M. J. (1997). When households run out of fuel: responses of rural households to decreasing fuelwood availability, Ntcheu District, Malawi. World Development, 25(2), 255-266. https://doi.org/10.1016/S0305-750X(96)00100-3

Burbidge, J. B., Magee, L., \& Leslie Robb, A. (1988). Alternative transformations to handle extreme values of the dependent variable. Journal of the American Statistical Association, 83(401), 123-127. https://doi.org/10.1080/01621459.1988.10478575

Cameron, S. V., \& Heckman, J. J. (1998). Life Cycle Schooling and Dynamic Selection Bias: Models and Evidence for Five Cohorts of American Males. Journal of Political Economy, 106(2), 262-333. https://doi.org/10.1086/250010

Cattaneo, A., \& Robinson, S. (2019). Economic development and the evolution of internal migration: moving in steps, returnees, and gender differences (FAO Agricultural Development Economics Working Paper No. 19-03). FAO. http://www.fao.org/3/ca3359en/CA3359EN.pdf

Central Statistical Office. (2016). 2015 Living Conditions Monitoring Survey (LCMS) report. Retrieved from Republic of Zambia Central Statistical Office website: https://www.zamstats.gov.zm/

Chakrabarti, A. (2019). Three essays on child wellbeing in developing countries (Doctoral dissertation, University of North Carolina at Chapel Hill, Chapel Hill, USA). Retrieved from https://cdr. lib.unc.edu/concern/dissertations/c534ft055

Chen, L., Heerink, N., \& van den Berg, M. (2006). Energy consumption in rural China: A household model for three villages in Jiangxi Province. Ecological Economics, 58(2), 407-420. https://doi. org/10.1016/j.ecolecon.2005.07.018

Chort, I., \& de la Rupelle, M. (2016). Determinants of Mexico-U.S. Outward and return migration flows: a state-level panel data analysis. Demography, 53(5), 1453-1476. https://doi.org/10.1007/ s13524-016-0503-9

Christiaensen, L., De Weerdt, J., \& Kanbur, R. (2019). Decomposing the contribution of migration to poverty reduction: methodology and application to Tanzania. Applied Economics Letters, 26(12), 978-982. 
Crankshaw, O., \& Borel-Saladin, J. (2019). Causes of urbanisation and counter-urbanisation in Zambia: natural population increase or migration? Urban Studies, 56(10), 2005-2020. https://doi.org/ 10.1177/0042098018787964

De Haas, H. (2010). Migration and development: a theoretical perspective. International migration review, 44(1), 227-264.

Demographic, Z., \& Survey, H. (2007). Calverton. Central Statistical Office/Zambia and Macro International Inc.

Ezzati, M., \& Kammen, D. M. (2002). The health impacts of exposure to indoor air pollution from solid fuels in developing countries: knowledge, gaps, and data needs. Environmental Health Perspectives, 110(11), 1057-1068.

Entwisle, B., Verdery, A., \& Williams, N. (2020). Climate change and migration: new insights from a dynamic model of out-migration and return migration. American Journal of Sociology, 125(6), 1469-1512. https://doi.org/10.1086/709463

Ferreira, F. H., Chen, S., Dabalen, A., Dikhanov, Y., Hamadeh, N., Jolliffe, D., \& Serajuddin, U. (2016). A global count of the extreme poor in 2012: data issues, methodology and initial results. The Journal of Economic Inequality, 14(2), 141-172.

Friedline, T., Masa, R. D., \& Chowa, G. A. (2015). Transforming wealth: using the inverse hyperbolic sine (IHS) and splines to predict youth's math achievement. Social science research, 49, 264-287. https://doi.org/10.1016/j.ssresearch.2014.08.018

Gong, Y. (2011). Does labour out-migration reduce firewood consumption? Presented at the International Seminar on Internal Migration and Urbanization and Their Socioeconomic Impacts in Developing Countries: Challenges and Policy Responses, Fuzhou, China. Retrieved from http:// archive.iussp.org/members/restricted/publications/Fuzhou11/Gong.pdf

Gupta, S., Pattillo, C. A., \& Wagh, S. (2009). Effect of remittances on poverty and financial development in sub-Saharan Africa. World Development, 37(1), 104-115. https://doi.org/10.1016/j. worlddev.2008.05.007

Handa, S., Natali, L., Seidenfeld, D., Tembo, G., Davis, B., \& Zambia Cash Transfer Evaluation Study Team. (2018). Can unconditional cash transfers raise long-term living standards? Evidence from Zambia. Journal of Development Economics, 133, 42-65.

Hansen, M. C., Potapov, P. V., Moore, R., Hancher, M., Turubanova, S. A., Tyukavina, A., \& Kommareddy, A. (2013). High-resolution global maps of 21st-century forest cover change. Science, 342(6160), 850853. Data available on-line from: http://earthenginepartners.appspot.com/science-2013-global-forest

Hedlund, H., \& Lundahl, M. (1983). Migration and change in rural Zambia. Nordiska Afrikainstitutet.

Heltberg, R. (2004). Fuel switching: evidence from eight developing countries. Energy Economics, 26(5), 869-887. https://doi.org/10.1016/j.eneco.2004.04.018

Hou, B., Tang, X., Ma, C., Liu, Li., Wei, Y., \& Liao, H. (2017). Cooking fuel choice in rural China: results from microdata. Journal of Cleaner Production, 142, 538-547. https://doi.org/10.1016/j. jclepro.2016.05.031

Hughes-Cromwick, E. L. (1985). Nairobi households and their energy use: an economic analysis of consumption patterns. Energy Economics, 7(4), 265-278. https://doi.org/10.1016/0140-9883(85)90048-9

IEA (2019), Africa Energy Outlook 2019, IEA, Paris. https://www.iea.org/reports/africa-energy-outlook-2019

IEA (2017), Energy Access Outlook 2017, IEA, Paris. https://www.iea.org/reports/energy-access-outlook-2017

IOM. (2019). Migration in Zambia: a country profile. International Organization for Migration (IOM). https://www.iom.int/sites/default/files/country/docs/zambia/zambia_migration_profile_2019.pdf

Jagger, P., \& Kittner, N. (2017). Deforestation and biomass fuel dynamics in Uganda. Biomass and Bioenergy, 105, 1-9. https://doi.org/10.1016/j.biombioe.2017.06.005

Jagger, P., \& Shively, G. (2014). Land use change, fuel use and respiratory health in Uganda. Energy Policy, 67, 713-726. https://doi.org/10.1016/j.enpol.2013.11.068

Jumbe, C. B. L., \& Angelsen, A. (2011). Modeling choice of fuelwood source among rural households in Malawi: a multinomial Probit analysis. Energy Economics, 33(5), 732-738. https://doi.org/10. 1016/j.eneco.2010.12.011

Karlson, K. B., Holm, A., \& Breen, R. (2012). Comparing regression coefficients between same-sample nested models using logit and probit: a new method. Sociological methodology, 42(1), 286-313.

Kegode, H. J. S., Oduol, J., Wario, A. R., Muriuki, J., Mpanda, M., \& Mowo, J. (2017). Households' choices of fuelwood sources: implications for agroforestry interventions in the Southern Highlands of Tanzania. Small-Scale Forestry, 16(4), 535-551. https://doi.org/10.1007/s11842-017-9369-y 
Komatsu, S., Ha, H., \& Kaneko, S. (2013). The effects of internal migration on residential energy consumption and CO2 emissions: a case study in Hanoi. Energy for Sustainable Development, 17, 572 580. https://doi.org/10.1016/j.esd.2013.10.002

Kim, K.-H., Jahan, S. A., \& Kabir, E. (2011). A review of diseases associated with household air pollution due to the use of biomass fuels. Journal of Hazardous Materials, 192(2), 425-431. https://doi. org/10.1016/j.jhazmat.2011.05.087

Link, C. F., Axinn, W. G., Ghimire, D. J. (2012). Household energy consumption: community context and the fuelwood transition. Social Science Research 41 (3), 598-611.

Lokshin, M., Bontch-Osmolovski, M., \& Glinskaya, E. (2010). Work-related migration and poverty reduction in Nepal. Review of Development Economics, 14(2), 323-332. https://doi.org/10.1111/j. 1467-9361.2010.00555.x

Makonese, T., Ifegbesan, A. P., \& Rampedi, I. T. (2018). Household cooking fuel use patterns and determinants across southern Africa: evidence from the demographic and health survey data. Energy \& Environment, 29(1), 29-48. https://doi.org/10.1177/0958305X17739475

Manning, D. T., \& Taylor, J. E. (2014). Migration and fuel use in rural Mexico. Ecological Economics, 102, 126-136. https://doi.org/10.1016/j.ecolecon.2014.03.012

Massey, D. S., Durand, J., \& Pren, K. A. (2016). Why border enforcement backfired. American Journal of Sociology, 121(5), 1557-1600. https://doi.org/10.1086/684200

Massey, D. (1990). Social structure, household strategies, and the cumulative causation of migration. Population Index, 56(1), 3-26.

Massey, D. S., Arango, J., Hugo, G., Kouaouci, A., Pellegrino, A., \& Taylor, J. E. (1993). Theories of international migration: a review and appraisal. Population and Development Review, 19(3), 431466. https://doi.org/10.2307/2938462

Megevand, C., Mosnier, A., Hourticq, J., Sanders, K., Doetinchem, N., \& Streck, C. (2013). Deforestation trends in the Congo basin: reconciling economic growth and forest protection. The World Bank. https://doi.org/10.1596/978-0-8213-9742-8

Mlambo, D., \& Huizing, H. (2004). Household responses to fuelwood scarcity: a case study of two villages in Zimbabwe. Land Degradation \& Development, 15(3), 271-281. https://doi.org/10.1002/ldr. 614

Mood, C. (2010). Logistic regression: why we cannot do what we think we can do, and what we can do about it. European sociological review, 26(1), 67-82.

Moran-Taylor, M. J., \& Taylor, M. J. (2010). Land and leña: linking transnational migration, natural resources, and the environment in Guatemala. Population and Environment, 32(2), 198-215. https:// doi.org/10.1007/s11111-010-0125-X

Muller, C., \& Yan, H. (2018). Household fuel use in developing countries: review of theory and evidence. Energy Economics, 70, 429-439. https://doi.org/10.1016/j.eneco.2018.01.024

Mueller, V., Gray, C., Handa, S., \& Seidenfeld, D. (2020). Do social protection programs foster shortterm and long-term migration adaptation strategies? Environment and Development Economics, 25(2), 135-158.

Oucho, J. O., \& Gould, W. T. (1993). Chapter 7: internal migration, urbanization, and population distribution. In Demographic Change in Sub-Saharan Africa (pp. 256-289). Washington, DC: National Academy Press. https://doi.org/10.17226/2207

Pence, K. M. (2006). The role of wealth transformations: an application to estimating the effect of tax incentives on saving. The BE Journal of Economic Analysis \& Policy, 5(1).

Piotrowski, M., \& Tong, Y. (2010). Economic and non-economic determinants of return migration: evidence from rural Thailand. Population, 65, 333-348.

Qin, H. (2010). Rural-to-urban labor migration, household livelihoods, and the rural environment in Chongqing Municipality. Southwest China. Human Ecology, 38(5), 675-690. https://doi.org/10. 1007/s10745-010-9353-z

Rahut, D. B., Behera, B., \& Ali, A. (2016). Patterns and determinants of household use of fuels for cooking: empirical evidence from sub-Saharan Africa. Energy, 117, 93-104. https://doi.org/10.1016/j. energy.2016.10.055

Ratha, D. (2013). The impact of remittances on economic growth and poverty reduction. Policy Brief, $8(1), 1-13$.

Rawat, Y. S., Vishvakarma, S. C., \& Todaria, N. P. (2009). Fuel wood consumption pattern of tribal communities in cold desert of the Lahaul valley, North-Western Himalaya. India. biomass and bioenergy, 33(11), 1547-1557. 
Rozelle, S., Taylor, J. E., \& deBrauw, A. (1999). Migration, remittances, and agricultural productivity in China. American Economic Review, 89(2), 287-291. https://doi.org/10.1257/aer.89.2.287

Ribot, J. C. (1999). A history of fear: imagining deforestation in the West African dryland forests. Global Ecology and Biogeography, 8(3-4), 291-300. https://doi.org/10.1046/j.1365-2699.1999.00146.x

Ru, M., Tao, S., Smith, K., Shen, G., Shen, H., Huang, Y., \& He, C. (2015). Direct energy consumption associated emissions by rural-to-urban migrants in Beijing. Environmental Science \& Technology, 49(22), 13708-13715. https://doi.org/10.1021/acs.est.5b03374

Shackleton, S. E., Shackleton, C. M., Netshiluvhi, T. R., Geach, B. S., Ballance, A., \& Fairbanks, D. H. K. (2002). Use patterns and value of savanna resources in three rural villages in South Africa. Economic Botany, 56(2), 130-146.

Seidenfeld, D., \& Handa, S. (2011). Zambia's Child Grant Program: baseline report. American Institutes for Research, Washington, DC., November.

Shen, H., Tao, S., Chen, Y., Ciais, P., Güneralp, B., Ru, M., Zhao, S. (2017). Urbanization-induced population migration has reduced ambient PM2.5 concentrations in China. Science Advances, 3(7), e1700300-e1700300. https://doi.org/10.1126/sciadv.1700300

Sherbinin, Alex de, Leah VanWey, Kendra McSweeney, Rimjhim Aggarwal, Alisson Barbieri, Sabina Henry, Lori M. Hunter, and Wayne Twine. (2008). Rural household demographics, livelihoods and the environment. Global Environmental Change. 2008 Feb; 18(1): 38-53. https://doi.org/10.1016/j. gloenvcha.2007.05.005

Song, C., Bilsborrow, R., Jagger, P., Zhang, Q., Chen, X., \& Huang, Q. (2018). Rural household energy use and its determinants in China: how important are influences of payment for ecosystem services vs. other factors? Ecological Economics, 145, 148-159. https://doi.org/10.1016/j.ecolecon.2017.08.028

Stark, O., \& Bloom, D. E. (1985). The new economics of labor migration. The American Economic Review, 75(2), 173-178.

Taylor, M. J., Moran-Taylor, M. J., Castellanos, E. J., \& Elías, S. (2011). Burning for sustainability: biomass energy, international migration, and the move to cleaner fuels and cookstoves in Guatemala. Annals of the Association of American Geographers, 101(4), 918-928. https://doi.org/10.1080/ 00045608.2011 .568881

Taylor, E. J. (1999). The new economics of labour migration and the role of remittances in the migration process. International migration, 37(1), 63-88.

United Nations. (2019). Remittances matter: 8 facts you don't know about the money migrants send back home. Retrieved from https://www.un.org/development/desa/en/news/population/remittances-matter. html

Van der Kroon, B., Brouwer, R., \& Van Beukering, P. J. (2013). The energy ladder: theoretical myth or empirical truth? Results from a meta-analysis. Renewable and Sustainable Energy Reviews, 20, 504-513.

Wang, C., Yang, Y., \& Zhang, Y. (2012). Rural household livelihood change, fuelwood substitution, and hilly ecosystem restoration: evidence from China. Renewable and Sustainable Energy Reviews, 16(5), 2475-2482.

West, C. T. (2009). Domestic transitions, desiccation, agricultural intensification, and livelihood diversification among rural households on the Central Plateau. Burkina Faso. American Anthropologist, 111(3), 275-288.

World Health Organization. (2018). Household aire pollution and health [Fact sheet]. https://www.who. $\mathrm{int} /$ news-room/fact-sheets/detail/household-air-pollution-and-health

Zulu, L. C., \& Richardson, R. B. (2013). Charcoal, livelihoods, and poverty reduction: evidence from sub-Saharan Africa. Energy for Sustainable Development, 17(2), 127-137. https://doi.org/10.1016/j. esd.2012.07.007

Publisher's Note Springer Nature remains neutral with regard to jurisdictional claims in published maps and institutional affiliations. 